\title{
ASSESSMENT OF CHANGES IN MICROSTRUCTURE AND HARDNESS OF BEARING STEEL FOR OPERATION AT A HIGH TEMPERATURE CAUSED BY SHORT-TERM OVERHEATING
}

\section{Ocena zmian mikrostruktury i twardości stali łożyskowej do pracy w podwyższonej temperaturze wywołanych krótkotrwałym przegrzaniem}

\begin{abstract}
The paper presented research results of the impact of short-term overheating of samples collected from the outer bearing ring suitable for the operation at elevated temperature installed in the turbine engine on the microstructure and hardness of the material. The samples were annealed at the following temperatures: 500, 600, 700, 800, 900 and $1000^{\circ} \mathrm{C}$; and then cooled in still air. Microstructure examinations were conducted under metallographic microscope and transmission electron microscope.
\end{abstract}

Keywords: rolling bearing, bearing steel, microstructure, hardness, light microscopy, TEM

Streszczenie: W publikacji przedstawiono wyniki badań wptywu krótkotrwałego nagrzewania próbek pobranych z pierścienia zewnętrznego tożyska przeznaczonego do pracy w podwyższonej temperaturze z silnika turbinowego na mikrostrukturę oraz twardość jego materiału. Próbki wygrzewano w temperaturach: 500, 600, 700, 800, 900 i $1000^{\circ} \mathrm{C}$, nastepnie studzono na spokojnym powietrzu. Badania mikrostruktury przeprowadzono, wykorzystując mikroskop metalograficzny oraz transmisyjny mikroskop elektronowy.

Słowa kluczowe: łożyska toczne, stal łożyskowa, mikrostruktura, twardość, mikroskopia świetlna, TEM 


\section{Introduction}

Operating conditions of turbine aircraft engines (high temperature, high rotational speeds of shafts [3]) require to apply appropriately strong materials in the production of bearings. To this end, steels with chemical composition and mechanical properties similar to high-speed tool steels [2] are applied. The characteristic feature of the above-mentioned steels is maintaining the stability of the structure and properties to temperatures up to $500^{\circ} \mathrm{C}$. Not the mention that these steels are rich in carbide-forming elements such as chromium, vanadium, tungsten and molybdenum. The exemplary steel grades destined to be used in elevated temperature were summarised in table 1 . The main manufacturing problem of this type of bearings is segregation of phase components and reduced thermal conductivity attributable to the increased number of alloying agents [4].

Table 1

Chemical composition of exemplary steel grades for steels applied in elevated temperature [5]

\begin{tabular}{|l|c|c|c|c|c|c|}
\hline \multirow{2}{*}{ Steel grades } & \multicolumn{7}{|c|}{ Chemical composition [\% wag.] } \\
\cline { 2 - 7 } & $\mathrm{C}$ & $\mathrm{Mn}$ & $\mathrm{Cr}$ & $\mathrm{Mo}$ & $\mathrm{V}$ & $\mathrm{W}$ \\
\hline M50 & 0,80 & 0,35 & 4,00 & 4,25 & 1,00 & - \\
\hline M1 & 0,83 & 0,30 & 3,75 & 8,50 & 1,15 & 1,75 \\
\hline M2 & 0,85 & - & 4,20 & 5,10 & 1,85 & 6,30 \\
\hline M62 & 1,30 & - & 3,75 & 10,5 & 2,00 & 6,25 \\
\hline T1 & 0,75 & - & 4,10 & - & 1,1 & 18,0 \\
\hline
\end{tabular}

High-speed steel ingots are characterized by a microstructure containing an eutectic matrix of high-melting (approx. $1240^{\circ} \mathrm{C}$ [1]) primary $\mathrm{MC}$ carbides (rich in vanadium) and $\mathrm{M}_{6} \mathrm{C}$ carbides (rich in tungsten and molybdenum) in the ferritic matrix with precipitates of $\mathrm{M}_{2} \mathrm{C}$ secondary carbides (rich in tungsten and molybdenum with the melting temperature of approx. $1100^{\circ} \mathrm{C}$ [3]) and $\mathrm{M}_{27} \mathrm{C}_{3}$ secondary carbides (rich in chromium with melting temperature of approx. $1000^{\circ} \mathrm{C}$ [3]) [4]. At the production stage, it is important to ensure high purity of the material. The matrix of primary carbides is broken up, the hot forging method is applied to obtain possibly fine and evenly distributed carbides to increase the fatigue strength of the steel and its resistance to abrasive wear. [3]. Carbides that are too big can experience the formation of microcracks, and it can also lead to the initiation of surface skinning, which could increase material wear [7, 8]. In the next stage, specimens are heated to the austenitization temperature (approx. $1100^{\circ} \mathrm{C}$ ) at the following temperatures: approx. 500 and $800^{\circ} \mathrm{C}$. After austenitization, two-stage cooling takes place: firstly, cooling in the salt bath up to approx. $580^{\circ} \mathrm{C}$, then in the air or in the oil up to the ambient temperature [2]. As a result of the performed heat treatment, the martensitic structure is formed with the 
large content of residual austenite, which reduces hardness, the dimensional stability of steel and primary carbides. To reduce the amount of residual austenite, it can be frozen immediately after cooling the feed. The final hardness of bearing steel is obtained after tempering it two or three times under $550^{\circ} \mathrm{C}$. It results in the transformation of residual austenite in martensite and precipitation of secondary carbides that increase material hardness as compared to the state immediately after hardening [4].

Overheating of bearings increases the number of precipitated carbides and its further growth. After exceeding the austenitization temperature and under the condition of rapid cooling, quenching of material occurs. Understanding the nature of phase transitions is necessary for estimating the condition of bearing materials and recognizing their wear mechanisms [6].

This paper aims to investigate the impact of short-term overheating at different temperatures on the microstructure and hardness of the Russian bearing steel, which is used at elevated temperature.

\section{Research methodology}

The research was focused on the outer bearing ring of Russian production suitable for the operation at elevated temperature. The chemical composition of the material was provided in table 2. The outer ring was cut into pieces and then annealed in the Heraeus M100 furnace during 30 minutes at $500,600,700,800,900$ and $1000^{\circ} \mathrm{C}$, and cooled in still air.

Table 2

Chemical composition of the bearing steel of Russian production

\begin{tabular}{|l|c|c|c|c|c|c|c|}
\hline \multicolumn{1}{|c|}{ Compound } & $\mathrm{C}$ & $\mathrm{Si}$ & $\mathrm{Mn}$ & $\mathrm{Cr}$ & $\mathrm{W}$ & $\mathrm{V}$ & $\mathrm{Fe}$ \\
\hline $\begin{array}{l}\text { Content } \\
{[\% \text { mass. }]}\end{array}$ & $0,7-0,8$ & $<0,4$ & $<0,4$ & $4,0-6,0$ & $8,5-9,5$ & $1,4-1,7$ & remains \\
\hline
\end{tabular}

The microstructure was analysed with the use of light and electron microscopy.

Preparation used for observations under light microscope were in the form of ground and mechanically polished microsections made of fragments of outer ring bearing which were cut across and then etched with two reagents: $2 \%$ vol. solution of nitric acid in ethanol (Nital) and $3 \mathrm{~g}$ solution of potassium ferricyanide, $10 \mathrm{~g}$ of sodium hydroxide, $100 \mathrm{ml}$ of distilled water (Murakami's reagent). Observations were done thanks to the use of a Nikon Eclipse MA200 metallographic microscope.

The test specimens for observations under TEM (transmission electron microscope) were made from disks with the diameter of $3 \mathrm{~mm}$ and width of $0,6 \mathrm{~mm}$ cut with the use of electrospark machining across the fragments of outer ring, which were gradually thinned on sandpaper with the increasing grit size to obtain the thickness of $0,1 \mathrm{~mm}$. The final thinning was performed with the application of TenuPol 5 electrolytic preparation 
equipment from Struers with $\mathrm{A} 3$ electrolyte $\mathrm{A} 3$ at $0^{\circ} \mathrm{C}$ and polishing voltage $22 \mathrm{~V}$. To observe tests samples under accelerating voltage $300 \mathrm{kV}$, high-resolution scanning transmission electron microscope FEI Titan in the Department of Investigations of Properties and Structure of Materials at the Institute of Ferrous Metallurgy in Gliwice in the south of Poland was applied.

Hardness measurements were conducted in the Laboratory for Material Research of Aerospace Designs accredited by the Polish Centre for Accreditation under the number AB-431. The measurements were carried out with the use of the Vickers method PN-EN ISO 6507-1:2007, applying DuraScan 20 hardness tester and load of $5 \mathrm{kG}$.

\section{Research results}

The microstructure of examined steel at the initial state shown by LM was illustrated in fig.1. The microstructure visible in microsection etched with Nital (fig. 1a) is of finecrystalline structure. The profiles of former austenite grain boundaries are observed (diameters in the order of several dozen of $\mu \mathrm{m}$ ). Within these boundaries exists martensite tempered with residual austenite and precipitation of carbides $[4,6]$.
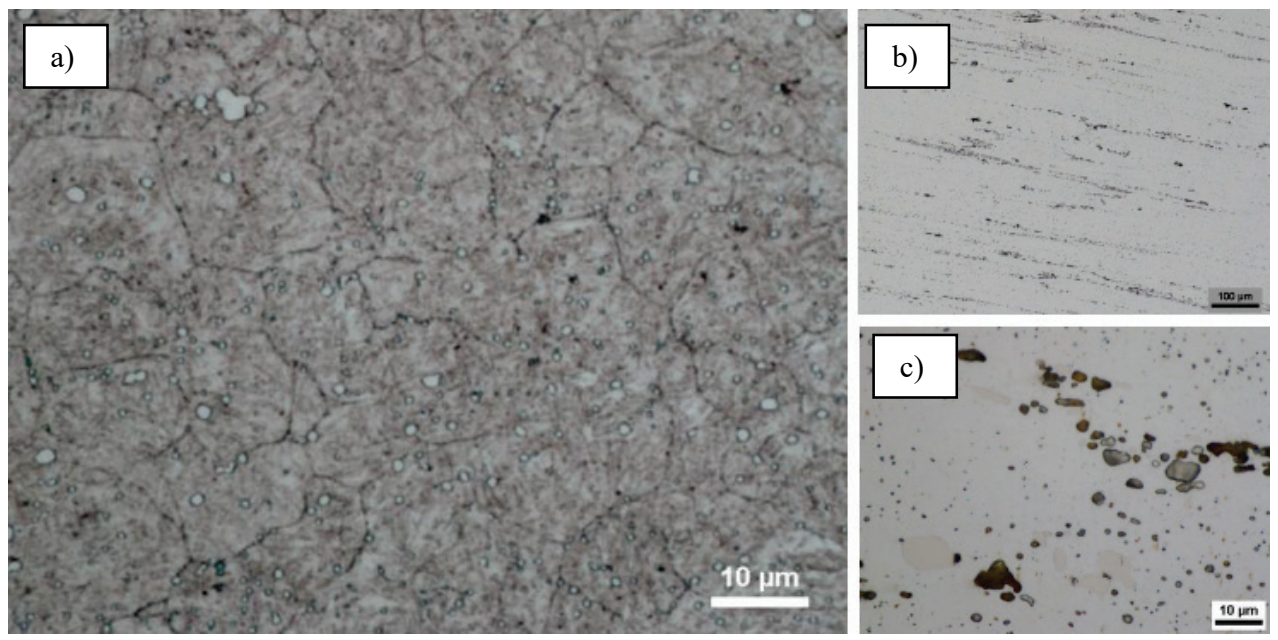

Fig. 1. Microstructure of the sample in the initial state, LM: a) microsection etched with Nital, b) microsection etched with the Murakami's reagent, c) enlargement of fig. $1 \mathrm{~b}$

The observations of microsection that were etched with the Murakami's reagent (fig. 1b) revealed the primary carbide laths, which resulted in the fragmentation of crystallizable carbides during alloy casting. It was seen in all test samples investigated in this paper. Fig. 1c exhibits the zone from fig. $1 \mathrm{~b}$ with higher magnification. We can notice primary carbides with diameters exceeding $1 \mu \mathrm{m}$ with clearly different colours related to the differences in the chemical composition: MC carbides were stained with a light colour 
under the influence of an etching reagent and $\mathrm{M} 6 \mathrm{C}$ carbides were stained with dark-brown colour [9]. Moreover, fine secondary carbides (below1 $\mu \mathrm{m}$ ) that formed during tempering are found. Fig. 2 presents the microstructure of the test sample revealed in TEM. Former austenite grain boundaries (fig. 2a), martensite laths in the vicinity of residual austenite and germs of secondary carbides (arrows in fig. 2b) are detected. A carbide with the dimension of approx. $500 \mathrm{~nm}$ was also observed.
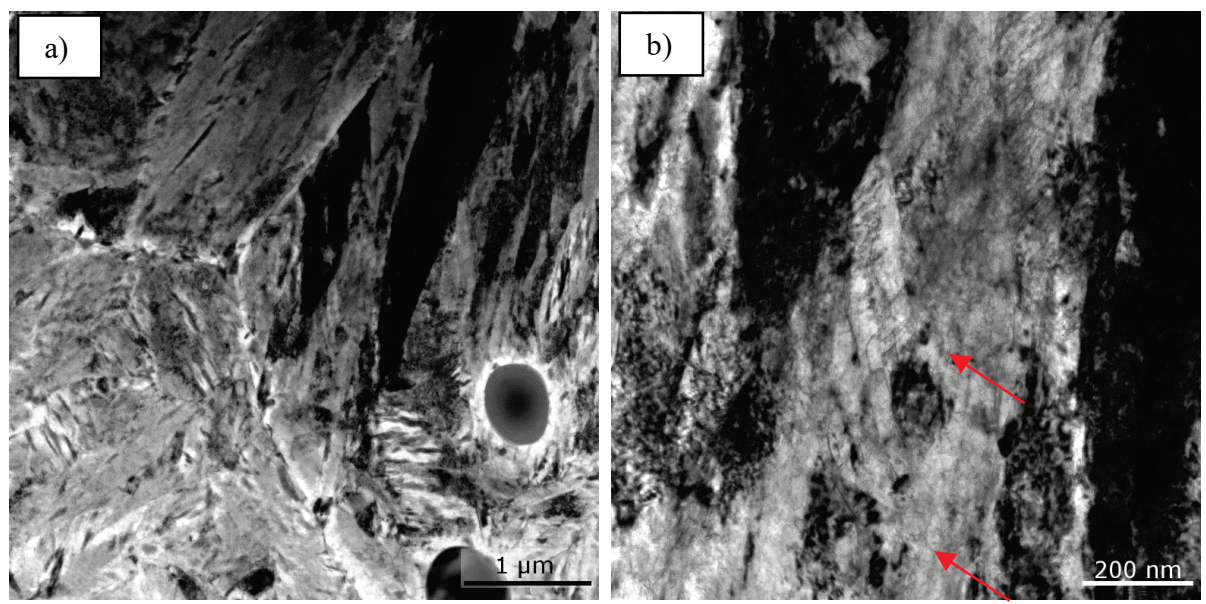

Fig. 2. The microstructure of the sample in its original state, TEM, bright field contrast, two magnifications of the same zone
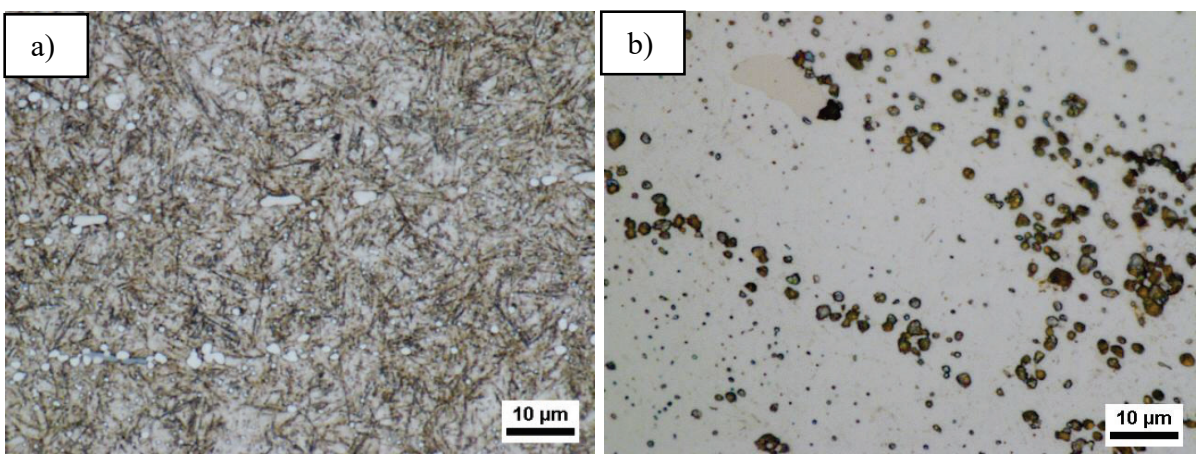

Fig. 3. The microstructure of the sample annealed at $500^{\circ} \mathrm{C}, \mathrm{LM}$ : a) microsection etched with Nital b) microsection etched with the Murakami's reagent

The images of the samples obtained via light microscopy (LM) that were annealed at $500^{\circ} \mathrm{C}$ and $600^{\circ} \mathrm{C}$ were illustrated in fig. $3 \mathrm{a}, 3 \mathrm{~b}$ and $4 \mathrm{a}, 4 \mathrm{~b}$. No significant changes are detected neither in the morpohology of temperated martensite (fig. 3a, 3c) nor in the distribution and the number of secondary carbides as compared to the sample in its original state. During examination under TEM, no significant alterations of a thin film made of the 
sample annealed at $600^{\circ} \mathrm{C}$ were observed: germs of secondary carbides and spheroidal carbides with diameters up to approx. $500 \mathrm{~nm}$ (fig. 5) were found in the matrix of tempered martensite. The temperatures of the above mentioned samples did not differ much from the tempering temperature of the material designed for the operation [3]; thus, no significant changes were found.
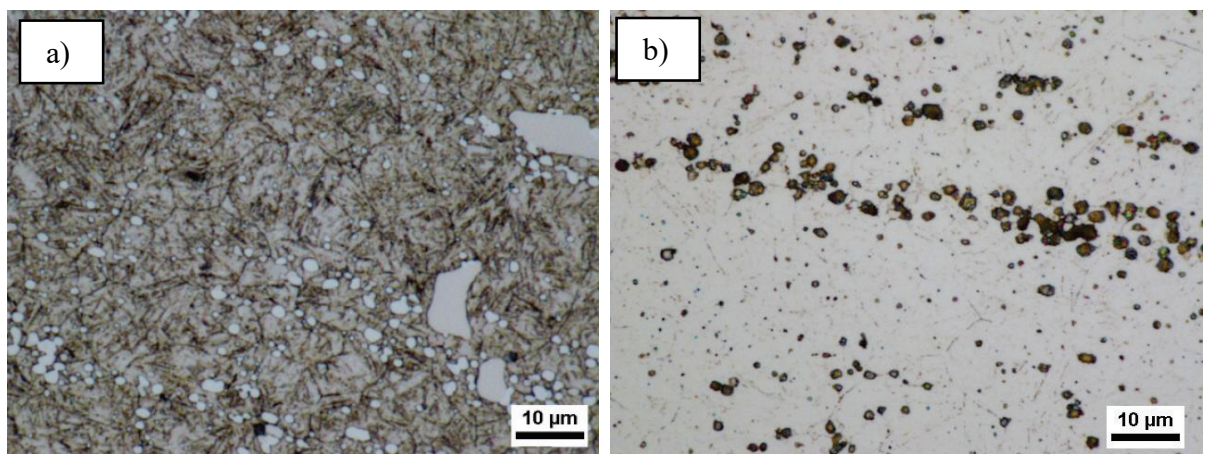

Fig. 4. Microstructure of the sample annealed at $600^{\circ} \mathrm{C}, \mathrm{LM}$ : a) microsection etched with Nital, b) microsection etched with the Murakami's reagent

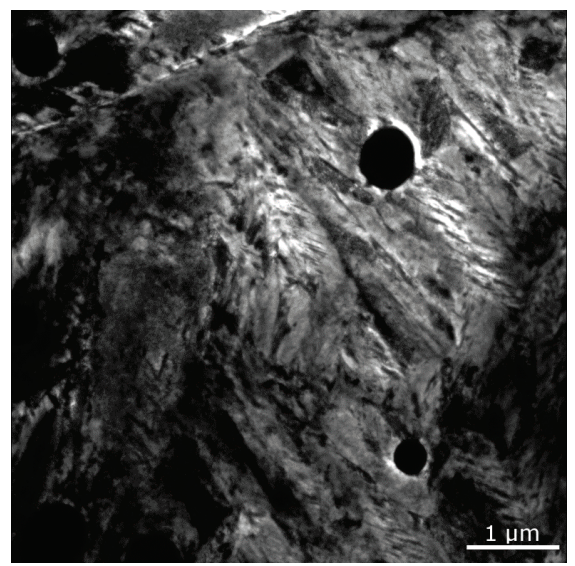

Fig. 5. Microstructure of the sample annealed at $600^{\circ} \mathrm{C}$, TEM, bright field contrast

Increasing the annealing temperature of samples up to $700^{\circ} \mathrm{C}$ and $800^{\circ} \mathrm{C}$ caused the occurrence of significant alterations in the microstructure (fig. 6 and 7). The shape of tempered martensite laths has changed (fig. 6a, 7a). The amount of the precipitation of fine secondary carbides increased (fig. 6b, 7b). The morphology and distribution of secondary carbides can be observed on TEM images of a thin film obtained from a sample annealed at $800^{\circ} \mathrm{C}$ (fig. 8). The carbides, which precipitated inside and on the boundaries of tempered martensite laths, differ in sizes up to approx. $500 \mathrm{~nm}$. They take spheroidal and oval forms. Also, between the carbides dislocation tangles can be found that form a cellular structure associated with recovery and recrystallization processes of the material. 

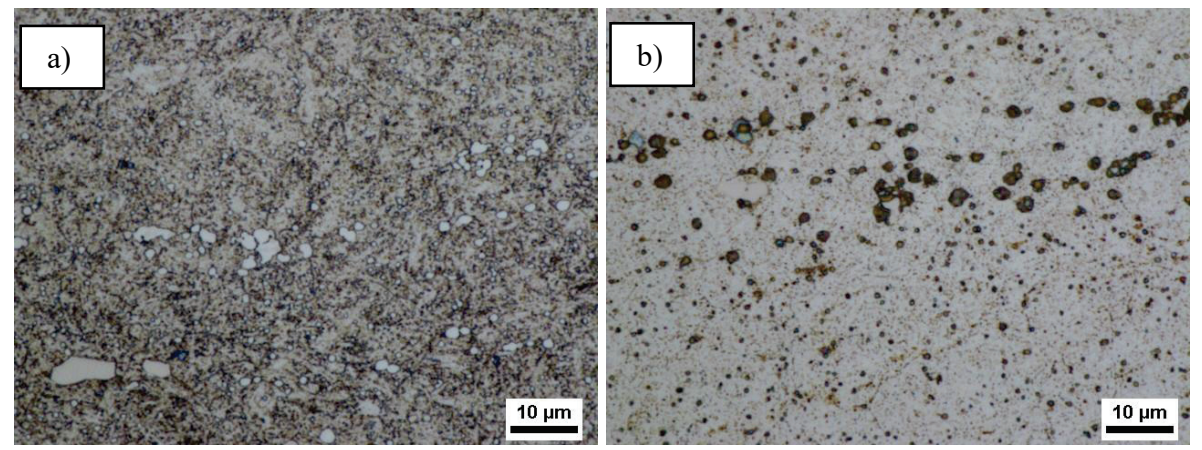

Fig. 6. Microstructure of a sample annealed at $700^{\circ} \mathrm{C}, \mathrm{LM}$ : a) microsection etched with Nital, b) microsection etched with the Murakami's reagent
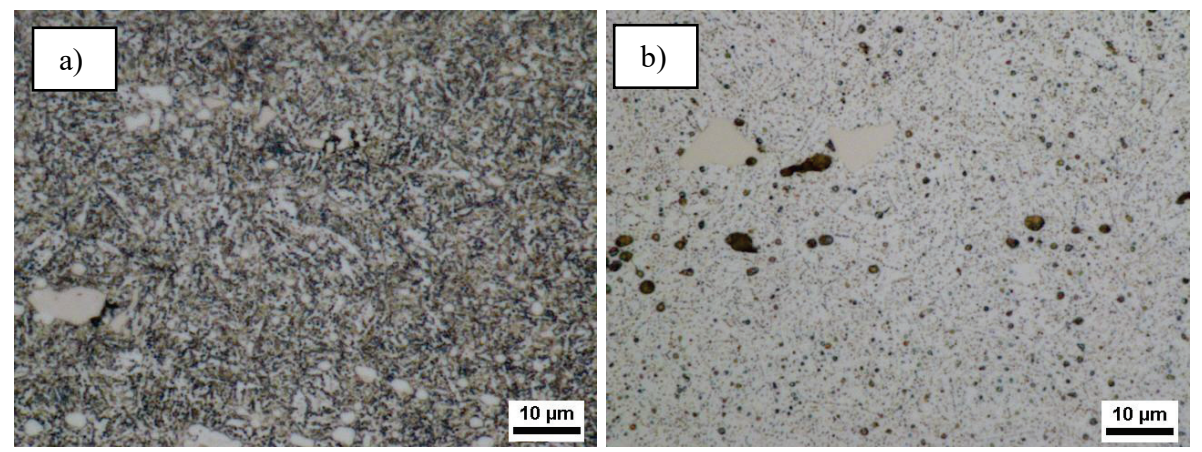

Fig. 7. Microstructure of a sample annealed at $800^{\circ} \mathrm{C}$, LM: a) microsection etched with Nital, b) microsection etched with the Murakami's reagent
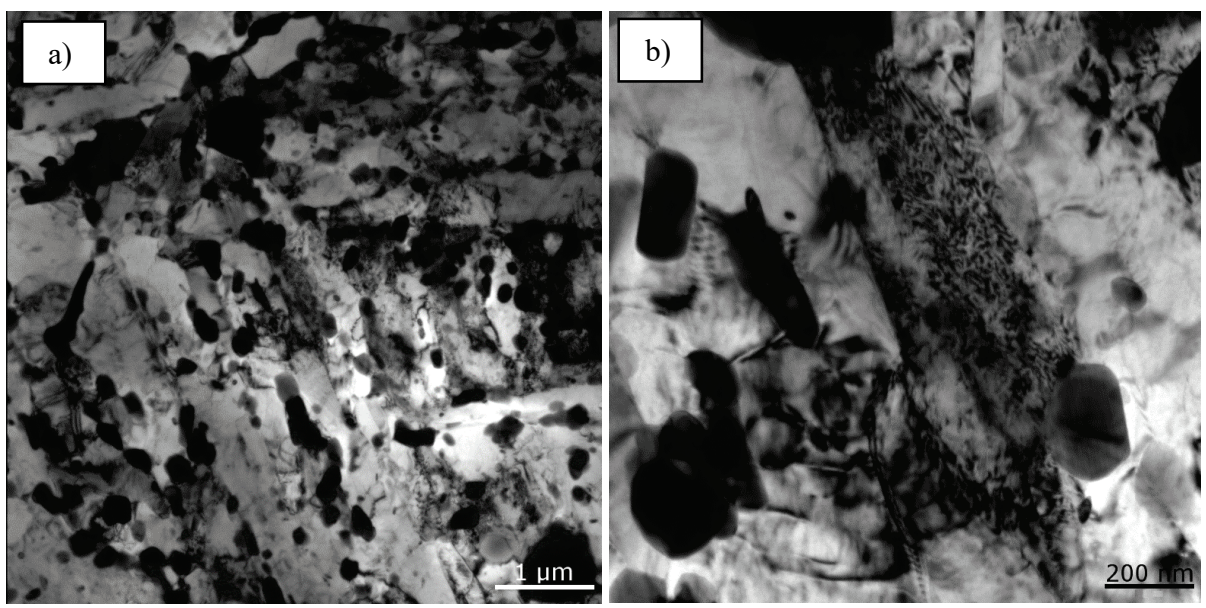

Fig. 8. Microstructure of a sample annealed at $800^{\circ} \mathrm{C}$, TEM, bright field contrast, the same area on two magnifications 
Annealing at $900^{\circ} \mathrm{C}$ led to exceeding the austenitization temperature, which, in combination with high hardenability of the tested steel grade, promoted the formation of martensitic structure (fig. 9a) with the primary and secondary carbides.
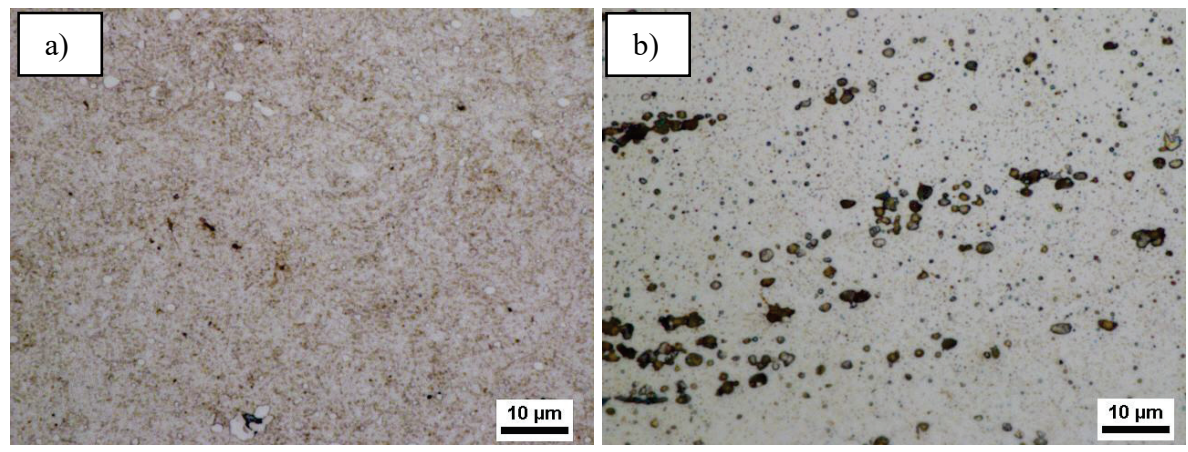

Fig. 9. Microstructure of the sample annealed at $900^{\circ} \mathrm{C}, \mathrm{LM}$ : a) microsection etched with Nital, b) microsection etched with the Murakami's reagent

The number of secondary carbides reduced (fig. 9b) as compared to the samples annealed at $700^{\circ} \mathrm{C}$ and $800^{\circ} \mathrm{C}$. The similar type of microstructure is seen under $\mathrm{LM}$ in the case of a sample annealed at $1000^{\circ} \mathrm{C}$ (fig. 11). Fig. 10a illustrates TEM imaging of the microstructure of a sample zone annealed at $900^{\circ} \mathrm{C}$. Secondary carbides are found in this sample zone. Figure 10b shows a microstructure of other zone of a thin film of the same sample with the visible martensite laths.
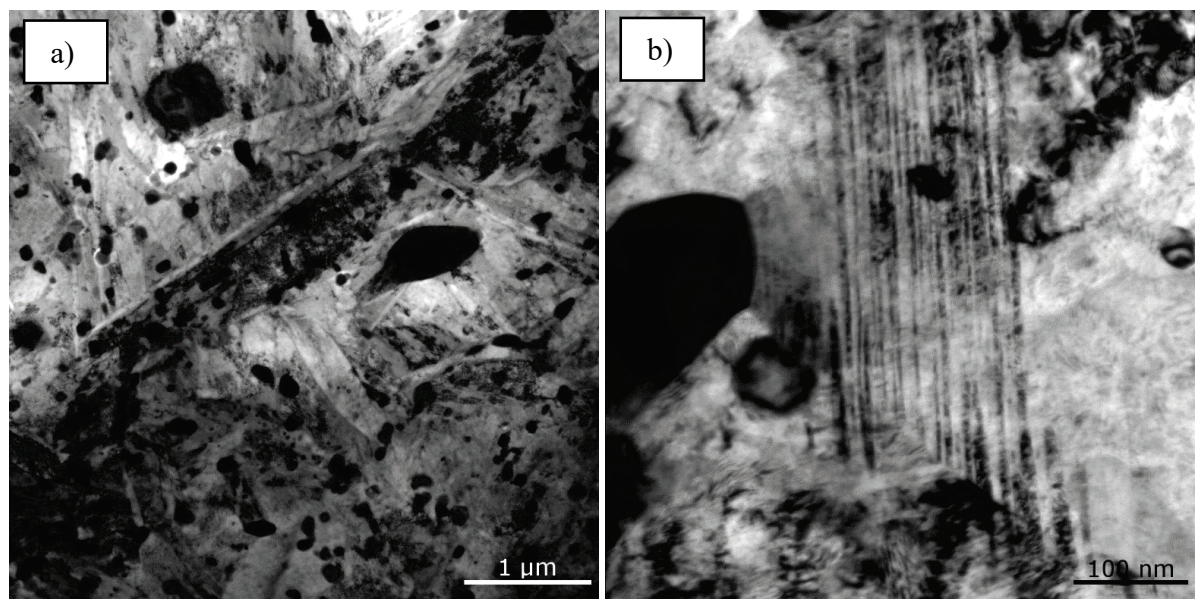

Fig. 10. Microstructure of the sample annealed at $900^{\circ} \mathrm{C}$, bright-field TEM, two different zones of a preparation 

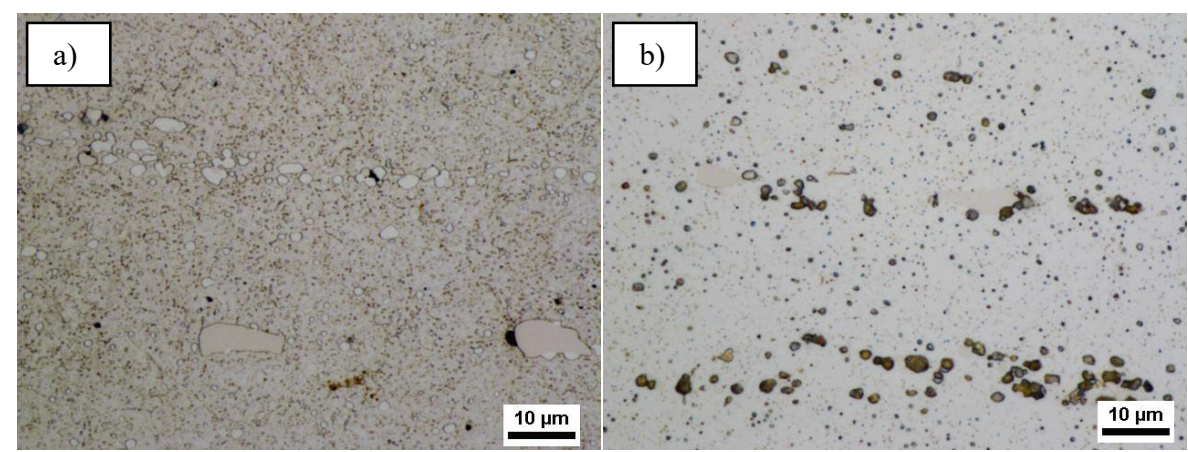

Fig. 11. Microstructure of the sample annealed at $1000^{\circ} \mathrm{C}, \mathrm{LM}$ : a) microsection etched with Nital, b) microsection etched with the Murakami's reagent

The microstructure of the sample annealed at $1000^{\circ} \mathrm{C}$ and visualized in bright-field TEM was presented in fig. 12a. There are observed martensite laths with residual austenite and carbides that were not dissolved during annealing. Figure $12 \mathrm{~b}$ demonstrates diffraction result in the selected field (with the area marked with a circle in figure 12a) with the visible reflexes of martensitic matrix and martensite twinning. Also, weak reflexes that can originate from carbides, are also noted. Dark-field TEM image in the reflex (-1 -2 -1) of a microstructure was performed that visualized a part of martensite laths (fig. 12.b).
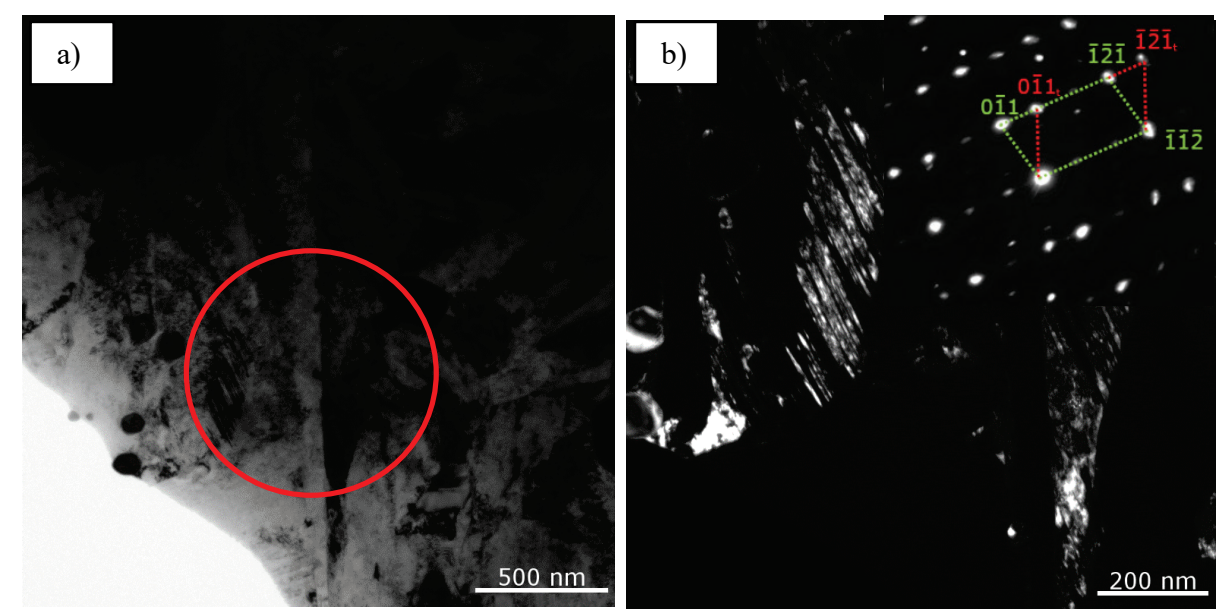

Fig. 12. Microstructure of the sample annealed at $1000^{\circ} \mathrm{C}$ : a) bright-field TEM b) dark-field TEM with a diffraction image (green contour indicates reflexes of matrix, red contour indicates reflexes of twin), image presented in fig. 12a in a higher magnification with a reflex (-1 -2 -1) 
Table 3 summarized the results of hardness measurements of all samples taken via the Vicker's method. In its initial state, the hardness of the steel sample was $787 \pm 5 \mathrm{HV} 5$, which is a correct value for this type of a bearing steel. Annealing at $500^{\circ} \mathrm{C}$ resulted in a slight decrease in hardness by $9 \mathrm{HV} 5$; and annealing at $600^{\circ} \mathrm{C}$ resulted in the reduction in hardness by 67 HV5. Relatively insignificant differences in hardness are due to the small differences between short-term heating temperatures and tempering temperature of a bearing.

Table 3

Summary of hardness measurement results with standard deviation values

\begin{tabular}{|l|c|c|c|c|c|c|c|}
\hline $\begin{array}{l}\text { Annealing } \\
\text { temperature } \\
{\left[{ }^{\circ} \mathrm{C}\right]}\end{array}$ & 0 & 500 & 600 & 700 & 800 & 900 & 1000 \\
\hline $\begin{array}{l}\text { Hardness } \\
{[\text { HV5 }]}\end{array}$ & $787 \pm 5$ & $778 \pm 4$ & $720 \pm 2$ & $434 \pm 2$ & $353 \pm 1$ & $683 \pm 6$ & $763 \pm 6$ \\
\hline
\end{tabular}

Increasing the annealing temperature up to $700^{\circ} \mathrm{C}$ and $800^{\circ} \mathrm{C}$ resulted in a further reduction in hardness by 354 and $434 \mathrm{HV} 5$ respectively, caused by the growth and increase in the number of secondary carbides; thus carbon depletion from the matrix. (increasing tempering intensity of the material). After annealing at $900^{\circ} \mathrm{C}$ and $1000^{\circ} \mathrm{C}$ lower hardness was obtained in comparison to the material in its original state with 104 and 24 HV5 respectively. Hardness of these samples is higher in relation to the samples annealed at $700^{\circ} \mathrm{C}$ and $800^{\circ} \mathrm{C}$ due to material quenching. Higher austenitization temperature promoted the saturation of austenite grains with higher amount of carbon (at the expense of dissolving carbides), which has an impact on increasing the hardness of matrix.

The values of standard deviations calculated for measurement results of all samples are considered to be small.

\section{Summary}

Chromium-tungsten-vanadium bearing steel samples were annealed for 30 minutes at the following temperatures: $500,600,700,800,900$ and $1000^{\circ} \mathrm{C}$, and then cooled in still air. It was found in the microstructure and hardness tests that the hardness decreased with the temperature increase in the range of $500-800^{\circ} \mathrm{C}$, which is due to carbide growth and the increase in numer of carbides. After cooling down from $900^{\circ} \mathrm{C}$ and $1000^{\circ} \mathrm{C}$, the hardness increased in relation to the previous group of samples due to the quenching of the material.

\section{Acknowledgements}

The authors would like to thank the Director of the Institute of Ferrous Metallurgy, Adam Zielinski, BEng, MSc, PhD, DSc, ProfTit, Assoc. Prof and Radosław Swadźba, BEng, MSc, PhD from the Laboratory for Investigations of Properties and Structure of Materials for 
the possibility to complete an internship during which the TEM tests of thin films for this study were carried out.

\section{References}

1. Barkalow R.H., Kraft R.W., Goldstein J.I.: Solidification of M2 high speed steel. Metallurgical and Materials Transactions B, 3(4), 1972.

2. Bayer A.M., Becherer B., Vasco T.: High-speed tool steels. ASM Handbook, 16, 1989.

3. Bhadeshia H.K.D.H.: Steels for bearings. Progress in Materials Science, 57, 2012.

4. Bliharski M.: Inżynieria Materiałowa. Stal. Wydawnictwa Naukowo-Techniczne, Warszawa 2004.

5. Hetzner D.W., Geertruyden W.: Crystallography and metallography of carbides in high alloy steels. Materials Characterization, 59(7), 2008.

6. Łęczycki K.: Wybrane problemy materiałowych badań łożysk tocznych przystosowanych do pracy w podwyższonych temperaturach. Przegląd Komunikacyjny, 73(9), 2018.

7. Rodenburg C., Rainforth W.M.: A quantitative analysis of the influence of carbides size distributions on wear behaviour of high-speed steel in dry rolling/sliding contact. Acta Materialia, 55, 2007.

8. Scott D., Blackwell J.: The effect of some manufacturing variables on the performance of high-speed tool-steel ball bearings. Wear, 18(1), 1971.

9. Staub F.: Stal. Atlas metalograficzny struktur, Wydawnictwa Naukowo-Techniczne, Warszawa 1964. 


\section{OCENA ZMIAN MIKROSTRUKTURY I TWARDOŚCI STALI LOŻYSKOWEJ DO PRACY W PODWYŻSZONEJ TEMPERATURZE WYWOLANYCH KRÓTKOTRWALYM PRZEGRZANIEM}

\section{Wprowadzenie}

Warunki pracy turbinowych silników lotniczych (wysoka temperatura, duże prędkości obrotowe wałów [3]) wymagają zastosowania w produkcji łożysk odpowiednio wytrzymałych materiałów. W tym celu wykorzystuje się stale zbliżone składem chemicznym i właściwościami mechanicznymi do narzędziowych stali szybkotnących [2], których charakterystyczną cechą jest zachowanie stabilności struktury i właściwości do temperatur rzędu $500^{\circ} \mathrm{C}$. Stale te są bogate w pierwiastki węglikotwórcze, takie jak: chrom, wanad, wolfram i/lub molibden. Przykładowe gatunki stali przeznaczonych do pracy $\mathrm{w}$ podwyższonych temperaturach zestawiono $\mathrm{w}$ tab. 1. Głównymi problemami związanymi z produkcją łożysk tego typu są segregacja składników fazowych oraz ograniczona przewodność cieplna związana z dużą ilością dodatków stopowych [4].

Tabela 1

Składy chemiczne przykładowych gatunków stali na łożyska do pracy w podwyższonych temperaturach [5]

\begin{tabular}{|l|c|c|c|c|c|c|}
\hline \multirow{2}{*}{$\begin{array}{l}\text { Gatunek } \\
\text { stali }\end{array}$} & \multicolumn{7}{|c|}{ Skład chemiczny [\% wag.] } \\
\cline { 2 - 7 } & $\mathrm{C}$ & $\mathrm{Mn}$ & $\mathrm{Cr}$ & $\mathrm{Mo}$ & $\mathrm{V}$ & $\mathrm{W}$ \\
\hline M50 & 0,80 & 0,35 & 4,00 & 4,25 & 1,00 & - \\
\hline M1 & 0,83 & 0,30 & 3,75 & 8,50 & 1,15 & 1,75 \\
\hline M2 & 0,85 & - & 4,20 & 5,10 & 1,85 & 6,30 \\
\hline M62 & 1,30 & - & 3,75 & 10,5 & 2,00 & 6,25 \\
\hline T1 & 0,75 & - & 4,10 & - & 1,1 & 18,0 \\
\hline
\end{tabular}

Wlewki stali typu szybkotnącego charakteryzuje mikrostruktura zawierająca eutektyczną siatkę wysokotopliwych (ok. $1240^{\circ} \mathrm{C}$ [1]) węglików pierwotnych typu MC (bogatych $\mathrm{w}$ wanad) oraz typu $\mathrm{M}_{6} \mathrm{C}$ (bogatych $\mathrm{w}$ wolfram $\mathrm{i} /$ lub molibden) w osnowie ferrytycznej $\mathrm{z}$ wydzieleniami węglików wtórnych typu $\mathrm{M}_{2} \mathrm{C}$ (bogatych w wolfram 
i molibden o temperaturze topnienia ok. $1100^{\circ} \mathrm{C}$ [3]) oraz typu $\mathrm{M}_{27} \mathrm{C}_{3}$ (bogatych w chrom, temperatura topnienia ok. $1000^{\circ} \mathrm{C}$ [3]) [4]. Na etapie wytwarzania wytopu ważne jest zadbanie o wysoką czystość materiału. Siatkę węglików pierwotnych rozbija się, stosując przekuwanie wlewków na gorąco do uzyskania możliwie drobnych i równomiernie rozłożonych węglików w celu zwiększenia odporności zmęczeniowej stali oraz jej odporności na zużycie ścierne [3]. Zbyt duże węgliki mogą sprzyjać powstawaniu mikropęknięć i inicjować łuszczenie powierzchni, przyspieszając zużycie materiału $[7,8]$. W następnym etapie przeprowadza się nagrzewanie do temperatury austenityzowania (rzędu $1100^{\circ} \mathrm{C}$ ) z dwoma przystankami w temperaturach ok. 500 i $800^{\circ} \mathrm{C}$. Po austenityzacji następuje dwustopniowe chłodzenie: najpierw w kąpieli solnej do temperatury ok. $580^{\circ} \mathrm{C}$, następnie na powietrzu lub $\mathrm{w}$ oleju do temperatury otoczenia [2]. W wyniku przeprowadzonej obróbki cieplnej uzyskuje się strukturę martenzytyczną z dużym udziałem austenitu szczątkowego ograniczającym twardość i stabilność wymiarową stali oraz węgliki pierwotne. W celu ograniczenia ilości austenitu szczątkowego można bezpośrednio po ostudzeniu wsadu przeprowadzić jego wymrażanie. Końcową twardość stali łożyskowej uzyskuje się po dwu- lub trzykrotnym odpuszczaniu w temperaturze ok. $550^{\circ} \mathrm{C}$, którego efektem jest przemiana austenitu szczątkowego w martenzyt i wydzielenie węglików wtórnych podwyższających twardość materiału w porównaniu do stanu bezpośrednio po hartowaniu [4].

Przegrzewanie łożysk skutkuje zwiększeniem ilości wydzielanych węglików oraz ich dalszym wzrostem. Po przekroczeniu temperatury przemiany austenitycznej i przy dostatecznie szybkim studzeniu dochodzi do ponownego zahartowania materiału. Poznanie natury przemian fazowych jest przydatne w ocenie stanu materiałów łożysk i poznaniu warunków ich niszczenia [6].

Celem niniejszego opracowania jest zbadanie wpływu krótkotrwałego przegrzewania w różnych temperaturach na mikrostrukturę i twardość stali łożyskowej produkcji rosyjskiej do pracy w podwyższonej temperaturze.

\section{Metodyka badań}

Przedmiot badań stanowił pierścień zewnętrzny łożyska produkcji rosyjskiej do pracy w podwyższonej temperaturze. Skład chemiczny materiału przedstawiono $w$ tab. 2 . Pierścień zewnętrzny pocięto na kawałki, które wygrzewano w piecu laboratoryjnym Heraeus M100 w atmosferze powietrza, przez 30 min w temperaturach 500, 600, 700, 800, $900,1000^{\circ} \mathrm{C}$, a następnie studzono na spokojnym powietrzu.

Tabela 2

Skład chemiczny stali łożyskowej rosyjskiej produkcji

\begin{tabular}{|l|l|l|l|l|l|l|l||}
\hline Pierwiastek & $\mathrm{C}$ & $\mathrm{Si}$ & $\mathrm{Mn}$ & $\mathrm{Cr}$ & $\mathrm{W}$ & $\mathrm{V}$ & $\mathrm{Fe}$ \\
\hline Udział [\% wag.] & $0,7-0,8$ & $<0,4$ & $<0,4$ & $4,0-6,0$ & $8,5-9,5$ & $1,4-1,7$ & reszta \\
\hline
\end{tabular}


Obserwacje mikrostruktury wykonano, wykorzystując mikroskopię świetlną i elektronową. Preparaty do obserwacji na mikroskopie świetlnym (ang. light microscope, LM) miały postać szlifowanych i polerowanych mechanicznie zgładów wykonanych z przekrojonych poprzecznie fragmentów pierścienia zewnętrznego łożyska, które następnie poddano trawieniu dwoma odczynnikami: roztwór $2 \%$ obj. kwasu azotowego w etanolu (nital) oraz roztwór $3 \mathrm{~g}$ żelazicyjanku potasu, $10 \mathrm{~g}$ wodorotlenku sodu $100 \mathrm{ml}$ wody destylowanej (odczynnik Murakamiego). Obserwacji wykonano z wykorzystaniem mikroskopu metalograficznego Nikon Eclipse MA200.

Preparaty do obserwacji $\mathrm{w}$ transmisyjnym mikroskopie elektronowym (ang. transmission electron microscope, TEM) wykonano z dysków o średnicy $3 \mathrm{~mm}$ i grubości 0,6 mm wyciętych elektroiskrowo w poprzek fragmentów pierścienia zewnętrznego, które stopniowo pocieniano na papierze ściernym o zwiększającej się gradacji ścierniwa do uzyskania grubości ok. 0,1 mm. Końcowy etap pocieniania wykonano elektrolitycznie z wykorzystaniem pocieniarki dwustrumieniowej TenuPol 5 elektrolitem A3 firmy Struers w temperaturze $0^{\circ} \mathrm{C}$ i napięciu polerowania $22 \mathrm{~V}$. Do obserwacji preparatów przy napięciu przyspieszającym $300 \mathrm{kV}$ wykorzystano wysokorozdzielczy skaningowo-transmisyjny mikroskop FEI Titan w Zakładzie Badania Struktury i Właściwości Materiałów Instytutu Metalurgii Żelaza w Gliwicach.

Pomiary twardości przeprowadzono w Laboratorium Materiałowych Badań Konstrukcji Lotniczych akredytowanym w Polskim Centrum Akredytacji pod numerem AB-431. Pomiary przeprowadzono metodą Vickersa PN-EN ISO 6507-1:2007, wykorzystując twardościomierz DuraScan 20 i obciążenie 5 kG.

\section{Wyniki badań}

Mikrostrukturę badanej stali w stanie wyjściowym zobrazowaną z wykorzystaniem LM przedstawiono na rys. 1. Obserwowana mikrostruktura na zgładzie trawionym nitalem (rys. 1a) jest drobnokrystaliczna, widoczne są zarysy granic ziaren byłego austenitu (średnice są rzędu kilkudziesięciu $\mu \mathrm{m}$ ). W ich obrębie występuje martenzyt odpuszczony z austenitem szczątkowym i wydzieleniami węglików [4,6].

Obserwacje zgładu trawionego odczynnikiem Murakamiego (rys. 1b) uwydatniły pasmowe ułożenie węglików pierwotnych, wynikające $\mathrm{z}$ rozbicia siatki węglików krystalizujących w czasie odlewania stopu, co zaobserwowano w wszystkich badanych w niniejszej pracy próbkach. Na rys. 1c przedstawiono obszar z rys. 1b w większym powiększeniu. Widoczne są węgliki pierwotne o średnicach przekraczających $1 \mu \mathrm{m}$ o wyraźnie zróżnicowanych barwach związanych z różnicami składu chemicznego: węgliki typu MC zabarwiły się pod wpływem odczynnika trawiącego na jasny kolor, węgliki typu M6C na kolor ciemno-brunatny [9]. Ponadto obserwuje się drobne (poniżej $1 \mu \mathrm{m}$ ) węgliki wtórne powstałe w czasie odpuszczania. Na rys. 2 przedstawiono mikrostrukturę próbki ujawnioną w TEM. Widoczne są granice ziaren byłego austenitu (rys. 2a), listwy 
martenzytu w otoczeniu austenitu szczątkowego oraz zalążki węglików wtórnych (rys. 2b strzałki). Zaobserwowano również węglik o średnicy ok. $500 \mathrm{~nm}$.
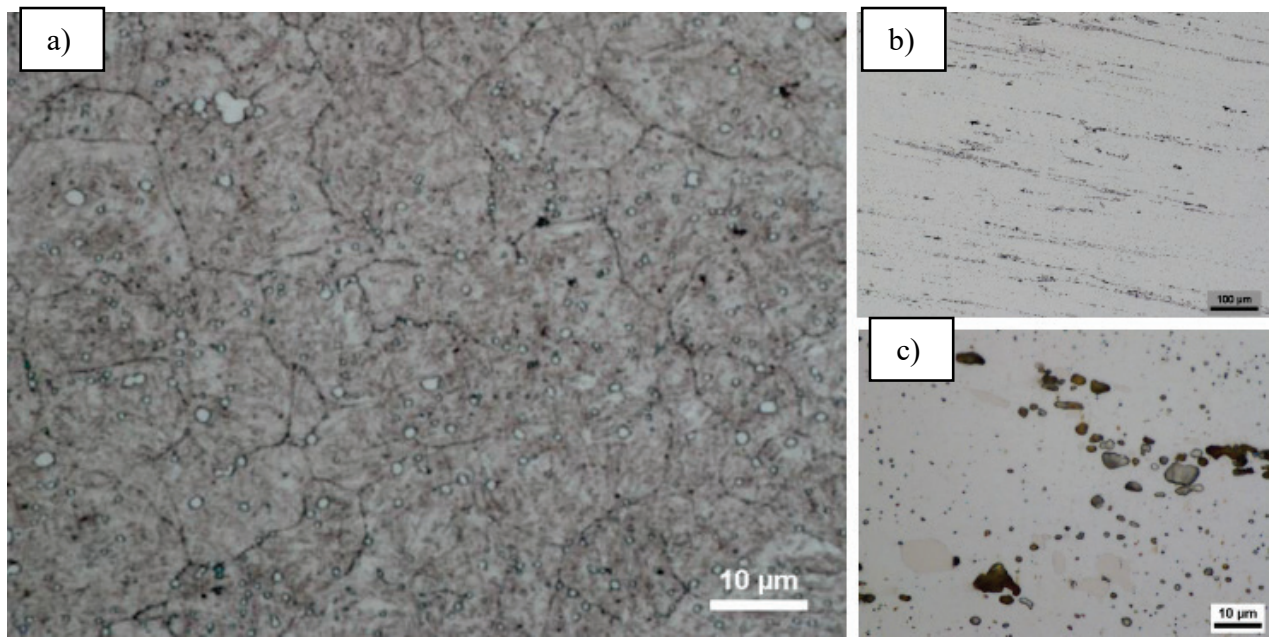

Rys. 1. Mikrostruktura próbki w stanie wyjściowym, LM: a) zgład trawiony nitalem, b) zgład trawiony odczynnikiem Murakamiego, c) powiększenie rys. 1b
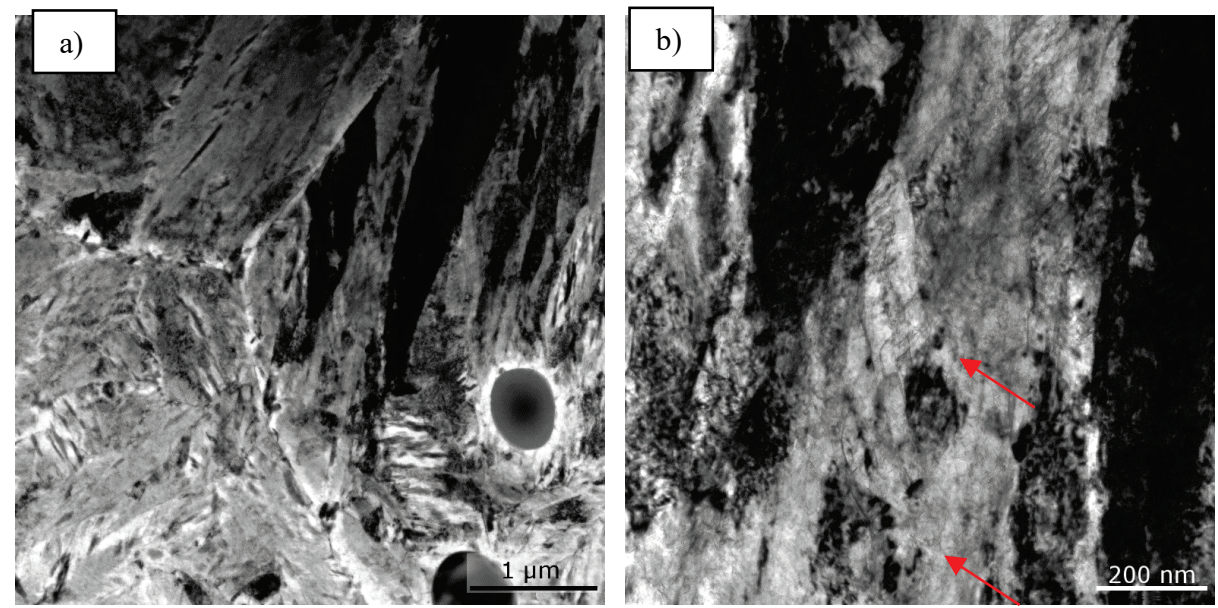

Rys. 2. Mikrostruktura próbki w stanie wyjściowym, TEM, kontrast jasnego pola, dwa powiększenia tego samego obszaru

Uzyskane z LM obrazy mikrostruktur próbek wygrzewanych w temperaturach $500^{\circ} \mathrm{C}$ i $600^{\circ} \mathrm{C}$ zobrazowano odpowiednio na rys. 3a, 3b oraz 4a, 4b. Nie obserwuje się wyraźnych zmian ani w morfologii odpuszczonego martenzytu (rys. 3a, 4a), ani w rozmieszczeniu oraz 
liczbie węglików wtórnych w porównaniu do próbki w stanie wyjściowym. Znaczących różnic nie wykryto również w czasie obserwacji w TEM cienkiej folii wykonanej z próbki wygrzewanej $\mathrm{w}$ temperaturze $600^{\circ} \mathrm{C}$ : w osnowie martenzytu odpuszczonego znajdowały się zalążki węglików wtórnych oraz sferoidalne węgliki o średnicach do ok. $500 \mathrm{~nm}$ (rys. 5). Temperatury omówionych powyżej obróbek nie różniły się znacząco od temperatury odpuszczania materiału przeznaczonego do eksploatacji [3], stąd też brak wyraźnych zmian.
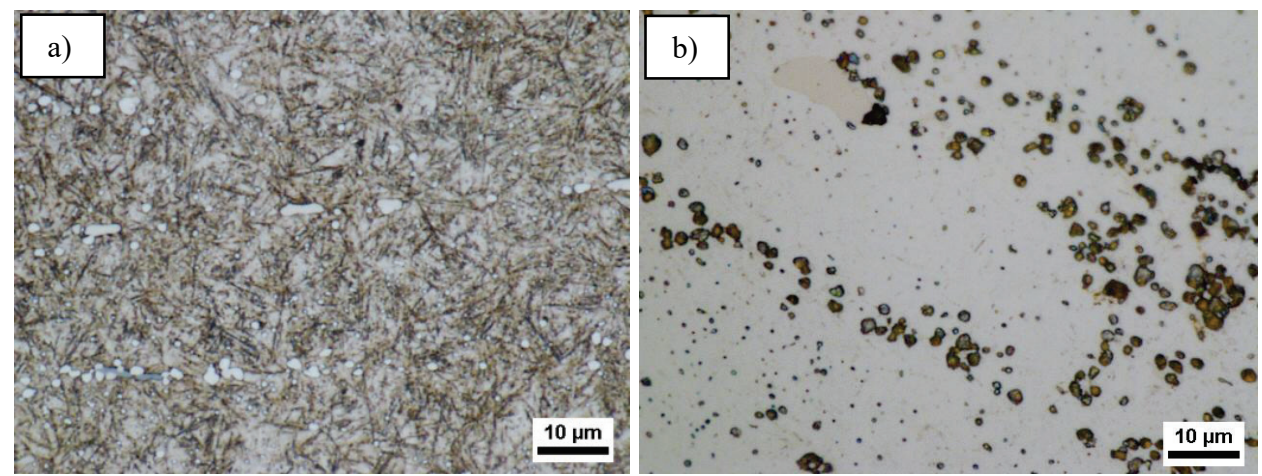

Rys. 3. Mikrostruktura próbki wygrzewanej $\mathrm{w}$ temp. $500^{\circ} \mathrm{C}, \mathrm{LM}$ : a) zgład trawiony nitalem, b) zgład trawiony odczynnikiem Murakamiego
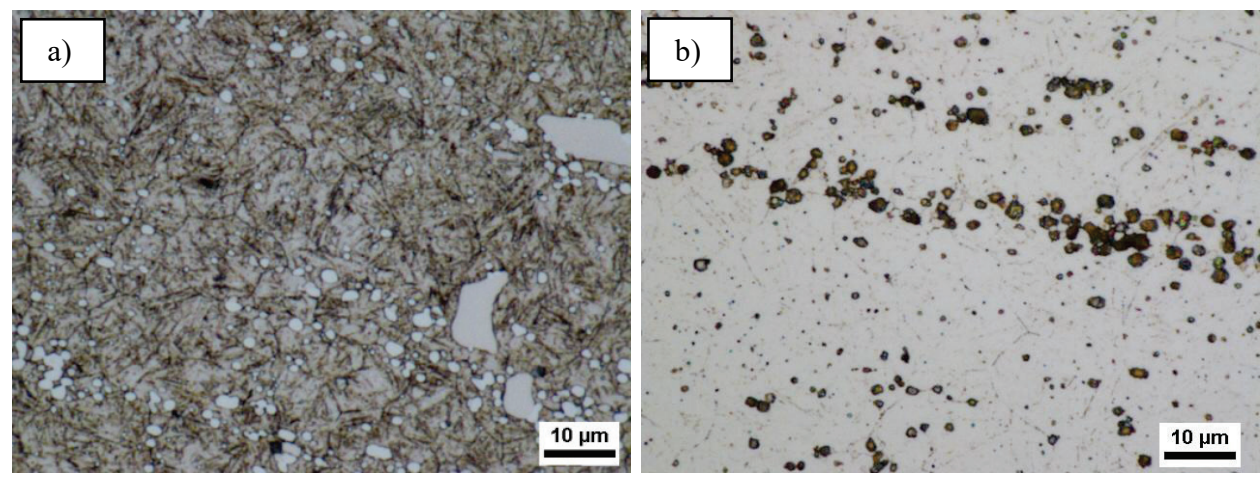

Rys. 4. Mikrostruktura próbki wygrzewanej $\mathrm{w}$ temp. $600^{\circ} \mathrm{C}, \mathrm{LM}$ : a) zgład trawiony nitalem, b) zgład trawiony odczynnikiem Murakamiego

Zwiększenie temperatury wygrzewania próbek do $700^{\circ} \mathrm{C}$ i $800^{\circ} \mathrm{C}$ spowodowało powstanie wyraźnych zmian w obrazach mikrostruktury (rys. 6 i 7). Kształt listew martenzytu odpuszczonego uległ zmianie (rys. 6a, 7a), zwiększeniu uległa ilość drobnych wydzieleń węglików wtórnych (rys. 6b, 7b). Morfologie i rozmieszczenie węglików wtórnych można zaobserwować na obrazach TEM cienkiej folii uzyskanej z próbki 
wygrzewanej $\mathrm{w} 800^{\circ} \mathrm{C}$ (rys. 8). Węgliki wydzieliły się wewnątrz oraz na granicach listew odpuszczonego martenzytu, mają zróżnicowane rozmiary do ok. $500 \mathrm{~nm}$. Przybierają kształty sferoidalne oraz zbliżone do owalnych. Pomiędzy węglikami widoczne są sploty dyslokacji tworzące strukturę komórkową związaną z zachodzeniem procesów zdrowienia i rekrystalizacji materiału.

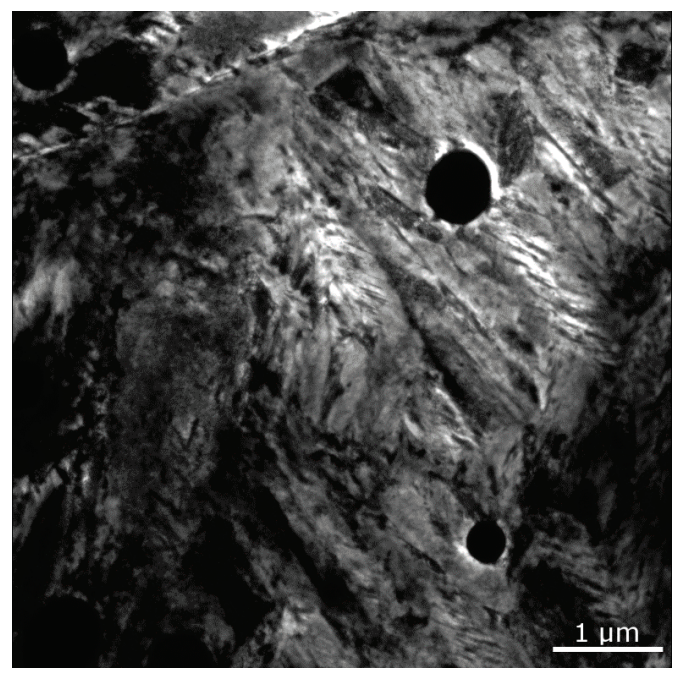

Rys. 5. Mikrostruktura próbki wygrzewanej w temperaturze $600^{\circ} \mathrm{C}$, TEM, kontrast jasnego pola
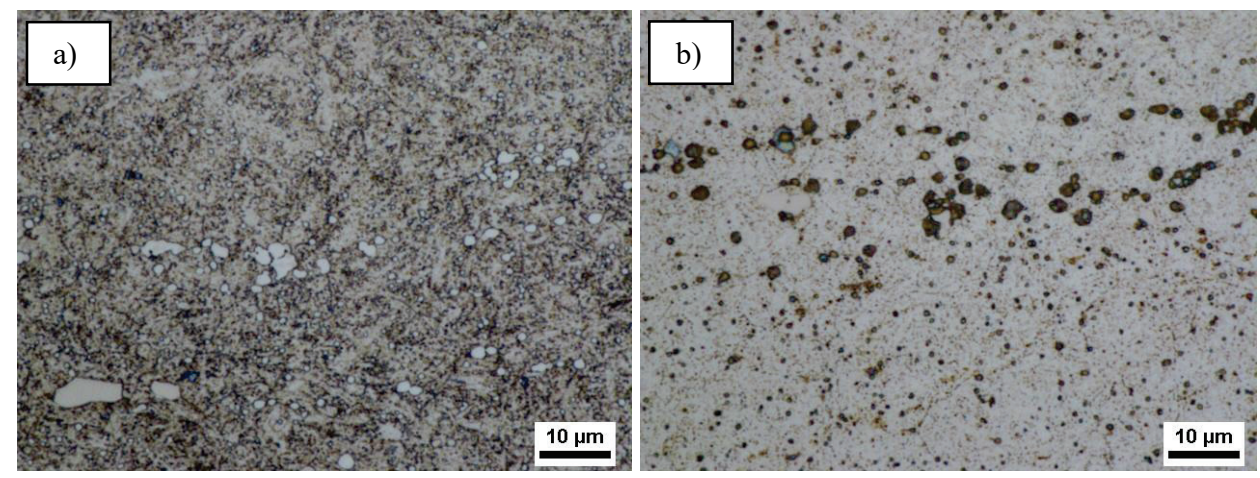

Rys. 6. Mikrostruktura próbki wygrzewanej w temp. $700^{\circ} \mathrm{C}, \mathrm{LM}$ : a) zgład trawiony nitalem, b) zgład trawiony odczynnikiem Murakamiego 

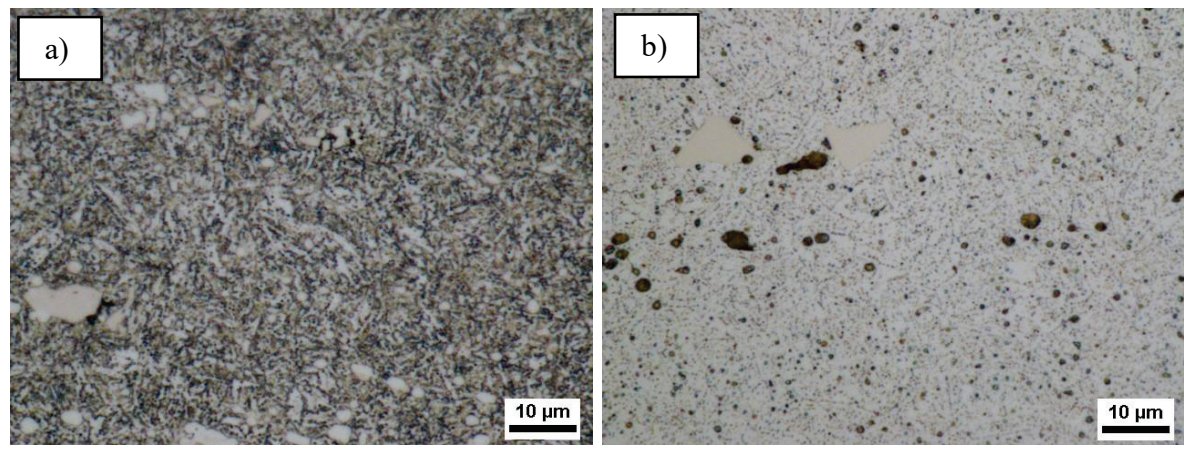

Rys. 7. Mikrostruktura próbki wygrzewanej w temp. $800^{\circ} \mathrm{C}, \mathrm{LM}$ : a) zgład trawiony nitalem, b) zgład trawiony odczynnikiem Murakamiego
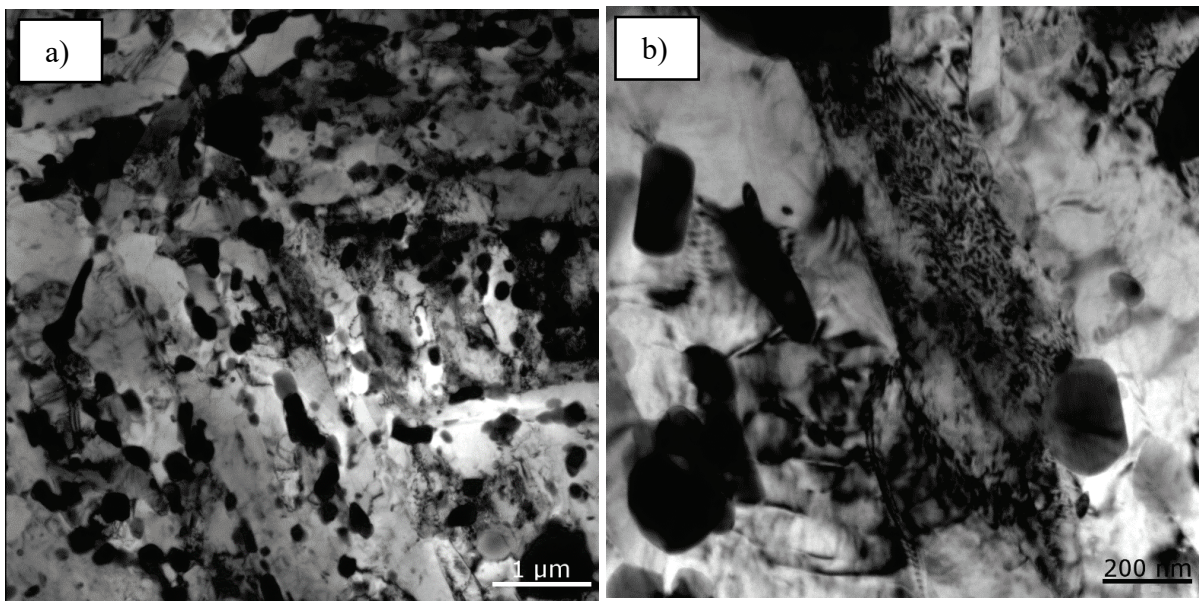

Rys. 8. Mikrostruktura próbki wygrzewanej w temp. $800^{\circ} \mathrm{C}$, TEM, w kontraście jasnego pola, ten sam obszar przy dwóch powiększeniach
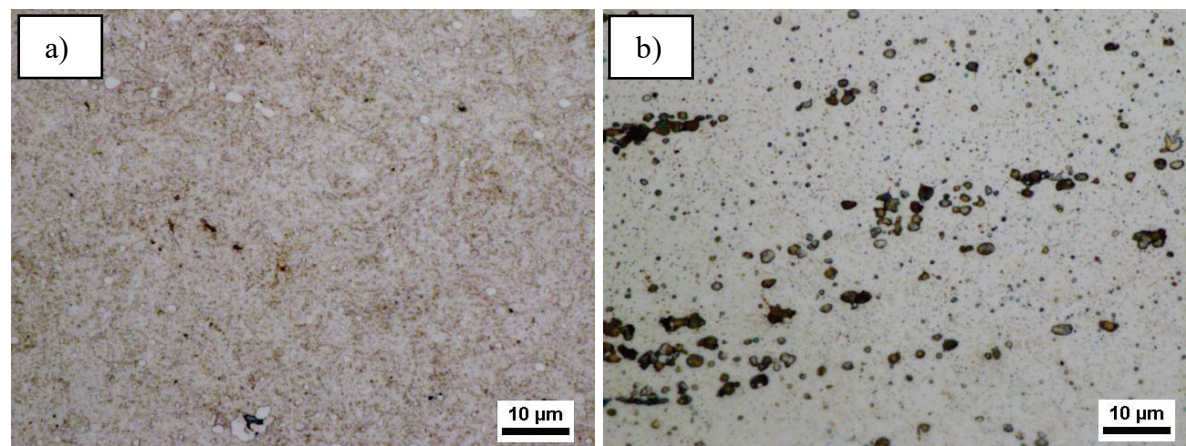

Rys. 9. Mikrostruktura próbki wygrzewanej w temp. $900^{\circ} \mathrm{C}, \mathrm{LM}$ : a) zgład trawiony nitalem, b) zgład trawiony odczynnikiem Murakamiego 
Wygrzewanie $\mathrm{w}$ temperaturze $900^{\circ} \mathrm{C}$ spowodowało przekroczenie temperatury austenityzacji, co w połączeniu z dużą hartownością badanego gatunku stali spowodowało powstanie struktury martenzytycznej (rys. 9a) z widocznymi węglikami pierwotnymi oraz wtórnymi.

Ilość węglików wtórnych uległa ograniczeniu (rys. 9b) w porównaniu do próbek wygrzewanych $\mathrm{w} 700^{\circ} \mathrm{C}$ i $800^{\circ} \mathrm{C}$. Zbliżony typ mikrostruktury obserwuje się w LM w przypadku próbki wygrzewanej w temperaturze $1000^{\circ} \mathrm{C}$ (rys. 11). Na rys. 10a przedstawiono mikrostrukturę obszaru próbki wygrzewanej w $900^{\circ} \mathrm{C}$ zobrazowaną $\mathrm{w}$ TEM, na którym widoczne są węgliki wtórne. Natomiast na rys. 10b pokazano mikrostrukturę innego obszaru cienkiej folii tej samej próbki z widocznymi listwami martenzytu. Mikrostrukturę próbki wygrzewanej w temperaturze $1000^{\circ} \mathrm{C}$ zobrazowaną $\mathrm{w}$ TEM w kontraście jasnego pola przedstawiono na rys. 12a. Widoczne są listwy martenzytu $\mathrm{z}$ austenitem szczątkowym oraz węglikami nierozpuszczonymi w czasie wygrzewania. $\mathrm{Na}$ rys. $12 \mathrm{~b}$ przedstawiono wynik dyfrakcji w wybranym polu ( $\mathrm{z}$ obszaru zaznaczonego okręgiem na rys. 12a) z widocznymi refleksami martenzytycznej osnowy oraz zbliźniaczeniami martenzytu. Widoczne są również słabe refleksy pochodzące prawdopodobnie od węglików. Wykonano obrazowanie mikrostruktury w ciemnym polu z refleksu (-1 -2 -1), w którym zobrazowano część listew martenzytu (rys. 12b).
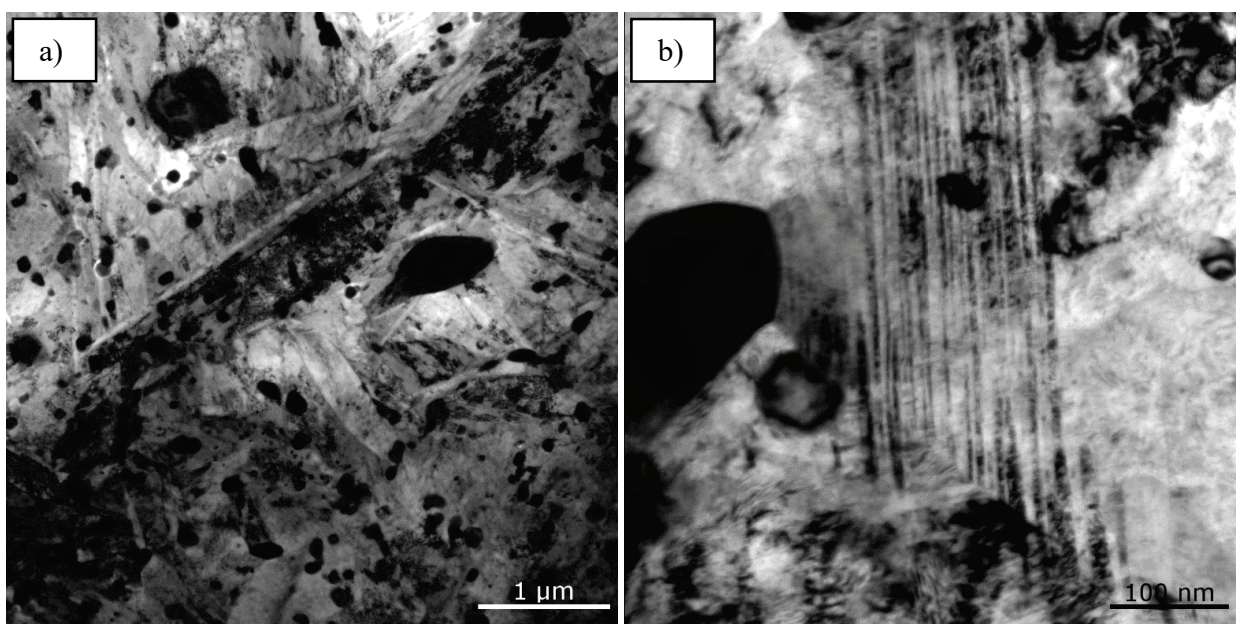

Rys. 10. Mikrostruktura próbki wygrzewanej w temp. $900^{\circ} \mathrm{C}$, TEM w kontraście jasnego pola, dwa różne miejsca preparatu 


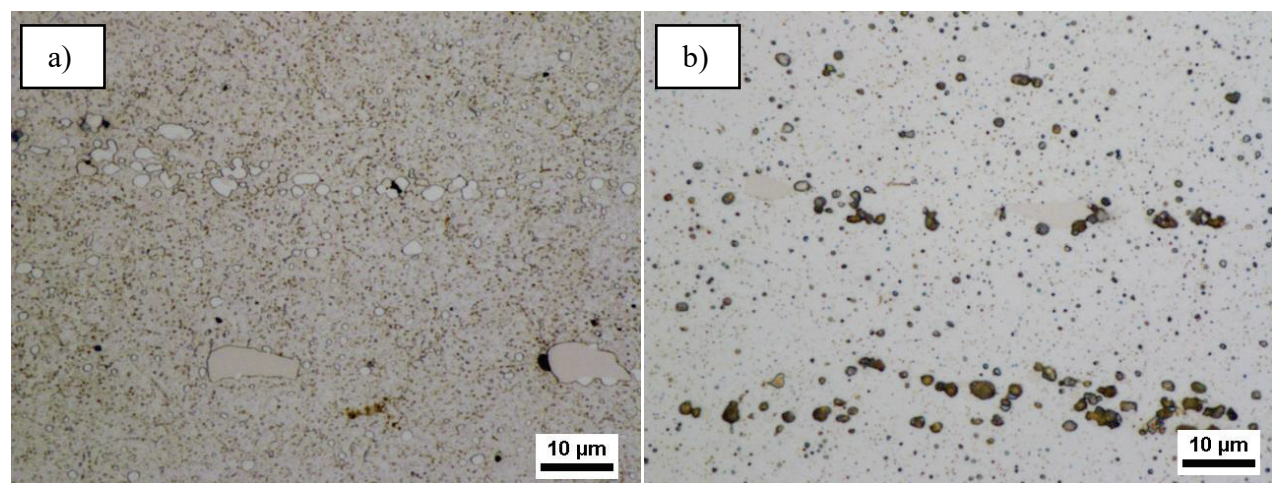

Rys. 11. Mikrostruktura próbki wygrzewanej w temp. $1000^{\circ} \mathrm{C}, \mathrm{LM}$ : a) zgład trawiony nitalem, b) zgład trawiony odczynnikiem Murakamiego
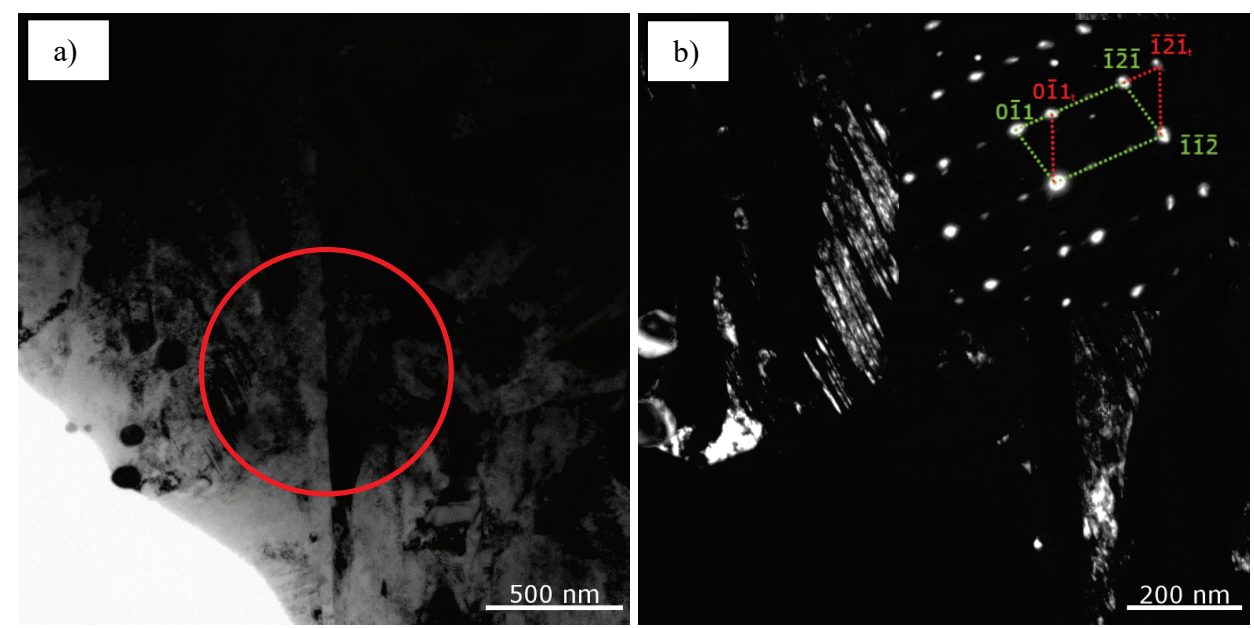

Rys. 12. Mikrostruktura próbki wygrzewanej w temp. $1000^{\circ} \mathrm{C}$ : a) TEM w kontraście jasnego pola, b) TEM w kontraście ciemnego pola $\mathrm{z}$ obrazem dyfrakcyjnym (zielony kontur refleksy osnowy, czerwony kontur refleksy bliźniaka), obszar pokazany na rys. 12 przy większym powiększeniu z refleksu (-1 -2 -1)

W tab. 3 zestawiono wyniki pomiarów twardości metodą Vickersa wszystkich próbek. Próbka stali w stanie wyjściowym wykazywała twardość $787 \pm 5$ HV5, co jest poprawną wartością dla tego typu stali łożyskowej. Wygrzewanie w temperaturze $500^{\circ} \mathrm{C}$ spowodowało nieznaczny spadek twardości o $9 \mathrm{HV} 5$, a wygrzewanie w temperaturze $600^{\circ} \mathrm{C}$ przyczyniło się do obniżenia twardości o 67 HV5. Stosunkowo niewielkie różnice twardości wynikają z małych różnic między temperaturami krótkotrwałego wygrzewania próbek a temperaturą odpuszczania łożyska. 
Tabela 3

Zestawienie wyników pomiarów twardości wraz z wartościami odchyleń standardowych

\begin{tabular}{|l|c|c|c|c|c|c|c||}
\hline $\begin{array}{l}\text { Temperatura } \\
\text { wygrzewania }\left[{ }^{\circ} \mathrm{C}\right]\end{array}$ & 0 & 500 & 600 & 700 & 800 & 900 & 1000 \\
\hline Twardość $[\mathrm{HV} 5]$ & $787 \pm 5$ & $778 \pm 4$ & $720 \pm 2$ & $434 \pm 2$ & $353 \pm 1$ & $683 \pm 6$ & $763 \pm 6$ \\
\hline
\end{tabular}

Podniesienie temperatury wygrzewania do $700^{\circ} \mathrm{C}$ i $800^{\circ} \mathrm{C}$ skutkowało dalszą redukcją twardości odpowiednio o 354 i 434 HV5, spowodowaną rozrostem i zwiększeniem liczby węglików wtórnych, a zatem zubożeniem osnowy w węgiel (zwiększenie stopnia odpuszczenia materiału). Po wygrzewaniu w temperaturach $900^{\circ} \mathrm{C}$ i $1000^{\circ} \mathrm{C}$ uzyskano twardość mniejszą w porównaniu do materiału w stanie wyjściowym o odpowiednio 104 i 24 HV5. Twardość tych próbek jest większa w porównaniu do próbek wygrzewanych w temperaturach $700^{\circ} \mathrm{C}$ i $800^{\circ} \mathrm{C}$ ze względu na ponowne zahartowanie materiału. Wyższa temperatura austenityzowania spowodowała nasycenia ziaren austenitu większą ilością węgla (kosztem rozpuszczenia węglików), co implikuje zwiększenie twardości osnowy.

Wartości odchyleń standardowych wyliczonych dla wyników pomiarów wszystkich próbek ocenia się jako niewielkie.

\section{Podsumowanie}

Przeprowadzono wygrzewanie próbek chromowo-wolframowo-wanadowej stali łożyskowej przez 30 min w temperaturach: 500, 600, 700, 800, 900 i $1000^{\circ} \mathrm{C}$, a następnie studzono na spokojnym powietrzu. W czasie badań mikrostruktury i twardości stwierdzono zmniejszenie twardości wraz ze wzrostem temperatury w zakresie $500-800^{\circ} \mathrm{C}$, co wynika z rozrostu i zwiększenia liczby węglików. Po studzeniu z temperatury $900^{\circ} \mathrm{C}$ i $1000^{\circ} \mathrm{C}$ twardość wzrastała względem wcześniejszej grupy próbek wskutek ponownego zahartowania materiału.

\section{Podziękowania}

Autorzy, pragna podziękować Dyrektorowi Instytutu Metalurgii Żelaza prof. nzw. dr. hab. Adamowi Zielińskiemu oraz dr. inż. Radosławowi Swadźbie z Pracowni Badań Właściwości i Struktury za umożliwienie odbycia stażu, w ramach którego przeprowadzono badania TEM cienkich folii do niniejszego opracowania. 


\section{Literatura}

1. Barkalow R.H., Kraft R.W., Goldstein J.I.: Solidification of M2 high speed steel. Metallurgical and Materials Transactions B, 3(4), 1972.

2. Bayer A.M., Becherer B., Vasco T.: High-speed tool steels. ASM Handbook, 16, 1989.

3. Bhadeshia H.K.D.H.: Steels for bearings. Progress in Materials Science, 57, 2012.

4. Bliharski M.: Inżynieria Materiałowa. Stal. Wydawnictwa Naukowo-Techniczne, Warszawa 2004.

5. Hetzner D.W., Geertruyden W.: Crystallography and metallography of carbides in high alloy steels. Materials Characterization, 59(7), 2008.

6. Łęczycki K.: Wybrane problemy materiałowych badań łożysk tocznych przystosowanych do pracy w podwyższonych temperaturach. Przegląd Komunikacyjny, 73(9), 2018.

7. Rodenburg C., Rainforth W.M.: A quantitative analysis of the influence of carbides size distributions on wear behaviour of high-speed steel in dry rolling/sliding contact. Acta Materialia, 55, 2007.

8. Scott D., Blackwell J.: The effect of some manufacturing variables on the performance of high-speed tool-steel ball bearings. Wear, 18(1), 1971.

9. Staub F.: Stal. Atlas metalograficzny struktur, Wydawnictwa Naukowo-Techniczne, Warszawa 1964. 